\title{
HOMERO E A QUESTÃO HOMÉRICA
}

\section{HOMER AND THE HOMERIC QUESTION}

Gustavo Frade

RESUMO: Uma investigação a respeito do entendimento de Homero e das abordagens de açáo no século

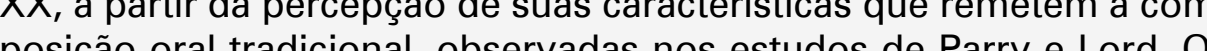
postos du investigram os fundamentos do estilo da composica dos pomas homéricos. Inclui considerã̃ do breves sobre a recep̧ão trancmissão na Antiguida partir do fin Xl do Ácul XVII (com o à helho semina de Wolf), passando pelo XIX tocando o ińcio do século XXI A partir dessa história sando pelo XIX e tocando o inicio do século XXI. A partir dessa historia

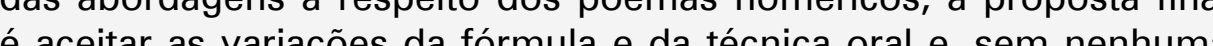

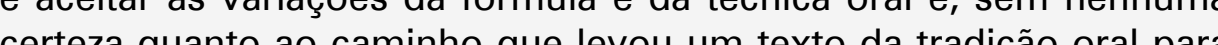
a tradição escrita, ler os poemas homéricos como poesia (com todos os reus recursos son que formam uma unidade.

PALAVRAS-CHAVE: Homero; questão homérica; fórmula; poesia oral.
* ghmfrade@gmail.com

Doutor em Letras e professor na Universidade Federal de Juiz de Fora.

ABSTRACT: This article is an investigation about the understanding of Homer and the reception of his epic poetry. The focus is the reception in the $20^{\text {th }}$ century, after the studies of Parry and Lord. The two tho the Homeric poes, paving the way to a seres of studies that won in

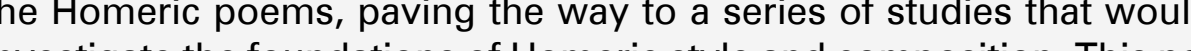
investigate the foundations of Homeric style and composition. This paper the process of fixing oral poetry in written tex the modern and contemporary reception, from the semal work of Wolf in the 18 century to Homeric scholarship the eging to some thoughts on reading the Homeric poems as poetry (with its soupho in into witen tradilon in Ancient Greece.

KEYWORDS: Homer; homeric question; formula; oral poetry. 


\section{INTRODUÇÃO}

Este artigo é uma investigação a respeito dos modos como aqueles que se dedicaram ao estudo da épica grega arcaica compreenderam Homero e seu estilo de composição ao longo dos tempos. Essa investigação, herdeira da Questão Homérica, o velho debate a respeito da identidade de Homero e da autoria da Ilíada e da Odisseia, terá como eixo central a percepção das características orais tradicionais desses poemas. $\mathrm{O}$ ponto de partida será a tentativa de alguns estudiosos de datar os poemas, seguida de uma breve exposição de como gregos do Período Arcaico e Clássico lidavam com a figura de Homero. Em seguida, após algumas considerações sobre o trabalho dos filólogos de Alexandria, serão recuperados o trabalho de Wolf (do final do século XVIII) e o método dos analistas do século XIX. Como um marco na trajetória dos estudos homéricos, será apresentada a teoria oral de Parry e Lord, assim como seus desdobramentos. A conclusão, sinteticamente, traz uma orientação possível para a interpretação dos poemas homéricos hoje.

\section{HOMERO NA ANTIGUIDADE ARCAICA E CLÁSSICA}

Estudiosos que se arriscaram a uma datação dos poemas que atribuímos a essa figura autoral de Homero sugeriram distintos intervalos temporais para sua composição. Os critérios, sintetizados por Kirk, em texto originalmente publicado em 1965, são os fenômenos datáveis (a rqueológicos, linguísticos e estilísticos) e os efeitos externos da táveis (possíveis referências à Ilíada ou à Odisseia em outros poemas, cenas pintadas em vasos, fundação de cultos de heróis, informações de escritores da Antiguidade). ${ }^{2} \mathrm{O}$ próprio Kirk conclui que os indícios apontam o fim do século VIII ou início do VII AEC como o período da composição dos poemas. Mais especificamente, para o que ele chama de "composição monumental": a produção de um poema longo, com um tema central bem definido construído a partir da tradição de histórias ou mesmo de canções que já circulavam antes. Embora afirme que não exista nenhum critério decisivo, ele acredita que poetas diferentes teriam composto a Ilíada, obra mais antiga, e a Odisseia, mais nova. ${ }^{3}$ Opinião semelhante tem Janko, que propõe (com precisão um pouco misteriosa, a inda que a menizada em seu próprio texto) o período entre 775 e 750 para a Ilíada e algo um pouco depois disso para a Odisseia. ${ }^{4}$ Contrário a essa opinião mais popular que vê o século VIII como período mais provável, Ruijgh, ao considerar certas diferenças entre o jônico homérico e o de Arquíloco, opta por seguir a opinião de Heródoto (II, 53, 2) e sugerir o século IX. ${ }^{5}$ A opinião de West é de que, pelas evidências das artes plásticas e de referências em outros poemas, a Ilíada parece circular desde mais ou menos $630 .{ }^{6} \mathrm{Uma}$ hipótese mais complexa de datação, que enfatiza de forma extrema o conceito de 
"movência" aplicado às composições de tradição oral, é levantada por Nagy e será comentada adiante. ${ }^{7}$

De todo modo, toda essa variação mostra que uma datação bem definida não é possível e nem mesmo um consenso a respeito de algum intervalo. Existe, no máximo, uma referência possível a uma versão escrita do final do século VI. A da ta sugerida por West para esse texto é 520; a que sugere Nagy é mais abrangente: a partir de $550 .{ }^{9}$ Seria, ainda que isso pareça ma is um elemento da construção mítica da imagem de um governante do que um dado confiável sobre a história da transmissão dos poemas, o texto registrado para a instituição da recitação da Ilíada e da Odisseia de Homero nas Grandes Panateneias, o festival ateniense.

No Hiparco (228b5), diálogo platônico considerado espúrio, foi esse tirano, Hiparco, filho de Pisístrato, que incluiu os poemas homéricos no programa do festival ateniense e promoveu o estabelecimento de uma versão escrita. No rela to transmitido por Diógenes Laércio (I, 57), os créditos são atribuídos a "Pisístrato ou Sólon". Era de interesse das monarquias e a ristocracias gregas se associar à manutenção e difusão das obras que se tornaram as grandes referências culturais pan-helênicas. Obras que compartilhavam de uma visão de mundo aristocrática tradicional e que, portanto, poderiam ser usadas para confirmar a autoridade e elevar o prestígio de figuras políticas. ${ }^{10}$ Xenofonte, em seu Banquete (III, 5), faz Nicerato, o ricaço a teniense, dizer que seu pai o obrigou a decorar a Ilíada e a Odisseia para que se tornasse um homem de valor ( $\dot{\alpha} \nu \dot{\eta} \rho \dot{\alpha} \gamma \alpha \theta$ óc). Estima-se que a leitura de Homero faria parte funda mental da educação dos ricos do século $\mathrm{V}$, embora não seja possível saber como exatamente se distribuía o acesso ao ensino (sempre particular) entre a população de uma cidade como Atenas. ${ }^{11}$

Homero torna-se também uma espécie de autoridade e uma referência de excelência poética para os compositores da elegia arcaica e da lírica coral. Nos primeiros versos do fragmento dubium $8 \mathrm{~W}$ ou el. 19 e 20, a tribuído por Estobeu (IV, 34, 28) a Simônides, uma imagem de Homero é citada para depois ser desdobrada: "Uma coisa, a mais bela, disse o homem de Quios: ${ }^{12}$ 'Como a geração das folhas, assim também é a dos homens.." ${ }^{13} \mathrm{O}$ verso é citado exatamente como aparece na Ilíada, VI, 146. O homem da ilha de Quios, portanto, seria o próprio Homero, e o compositor da elegia se apropria poeticamente de seu verso. Píndaro, introduzindo o elogio de um atleta vitorioso, menciona

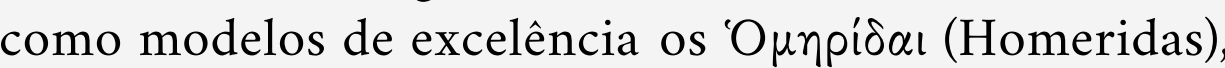
rapsodos que recitariam os poemas homéricos (Nemeia 2 , 1-5): "como os Homeridas começam por Zeus a maioria

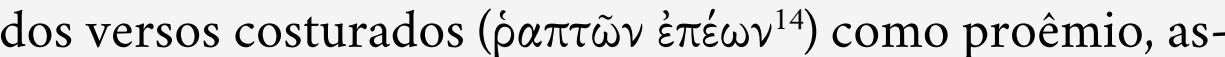
sim ta mbém este homem recebeu uma primeira entrada 
vitoriosa nos jogos sagrados, nos muito cantados bosques de Zeus na Nemeia." ${ }^{15}$ É preciso notar que até o século III ou II, textos diversos, como hinos e outros poemas épicos (incluindo o paródico Margites, mencionado na Poética de Aristóteles, 1448b) são atribuídos a Homero. Não havia ainda o estabelecimento de Homero especificamente como o autor da Ilíada e da Odisseia, ideia que predominará posteriormente. Além disso, mesmo as citações desses dois poemas (em Platão e Aristóteles, por exemplo) e os papiros preservados contêm versos que não correspondem ao texto que posteriormente será transmitido até os tempos atuais e que só a partir dessa época parecem formar um texto mais ou menos regular. ${ }^{16}$ Até então, a variação predomina.

Nos escólios (as anotações de leitores antigos nas margens ou entrelinhas dos manuscritos, transmitidas junto com o texto principal) à passagem de Píndaro acima mencionada, os Homeridas, possivelmente uma guilda de rapsodos profissionais, são identificados como inicialmente descendentes de Homero, ${ }^{17}$ mas que depois se tornam apenas artistas que executam as composições do poeta, sem nenhuma ligação de sangue. ${ }^{18}$ Todos os poemas de seu repertório eram atribuídos ao grande poeta cego ${ }^{19}$ do passado, de modo que a fama desse Homero e dos Homeridas se misturava e se espalhava. ${ }^{20} \mathrm{~A}$ hipótese de West é a seguinte: essa companhia de rapsodos do século VI poderia ter inventado a figura ancestral de Homero (a cegueira como característica é um toque verossímil, uma vez que ser cantor e compositor são atividades profissiona is possiveis e talvez comuns para um cego, como o próprio Demódoco da Odisseia). Poderia até mesmo ter inventado o nome Homero a partir do próprio nome de Homeridas (e não o contrário). ${ }^{21}$ West reúne três possibilidades para a formação do nome: a primeira é dada por Nagy com a formação a partir das raízes ó $\mu$ - e $\dot{\alpha} \rho$ - com sentido de "ajustar, unir" (como no verbo ó $\mu \eta \varepsilon \tilde{v} v$, "encontrar" e na expressão de Hesíodo na

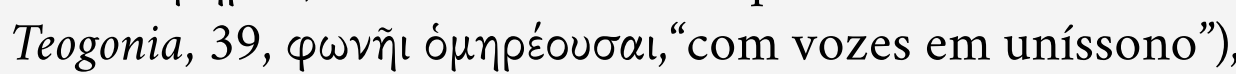
com o sentido de "o que junta (ou compõe) as canções";22 a segunda é a associação que aparece em algumas biografias mitológicas de Homero e dos Homeridas: ó $\mu \eta p$ - com o sentido de "refém"; a terceira, dada por Marcelo Durante

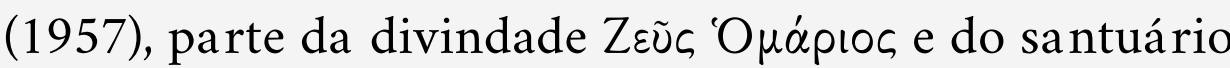

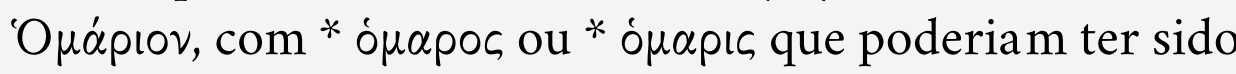
uma assembleia associada a concursos de poesia (um festival com premiação). ${ }^{23}$

São hipóteses que tentam rastrear a construção de uma identidade ou de uma figura de autoridade a partir de um nome. Uma perspectiva mais esclarecedora talvez seja pensar esse nome como uma maneira prática de se referir ao que há de melhor na tradição ou como "um modo de antropomorfizar a tradição poética". ${ }^{24}$ É ilustrativo o relato de 
Foley sobre a busca à primeira vista infrutífera do pesquisador Schmaus por Ćor Huso, bardo (guslar) servo-croata creditado por outros guslari como fonte de diversas canções épicas, mas que ninguém conheceu pessoalmente. Os relatos sobre o guslar lendário, cego como o Homero do Hino Homérico a Apolo, eram repletos de informações divergentes ou aparentemente fantasiosas. A conclusão de Foley é de que os cantores usaram Ćor Huso (ou o nome "Ćor Huso") como uma credencial de autoridade "para estabelecer sua própria herança bárdica e sua própria proeminência, assim como para marcar certas canções suas como as melhores.".

A busca por um autor, por um momento de composição ou estabelecimento do texto e por uma localização geográfica desses processos, apesar de intrigantes, ${ }^{26}$ não são o caminho para explicar a poesia homérica como fenômeno cultural. Homero, como será demonstrado a seguir, é um resultado do modo como são lidos os poemas a ele atribuídos. Tendo em mente que boa parte das particularidades de um texto se revela pela comparação com outros textos, que toda produção cultural resulta de uma sociedade específica, de um tempo específico e de uma região específica e que essa produção reverbera no seu próprio sistema cultural e também em outros com os quais se comunica, é a leitura dos textos e o enfrenta mento de seus problemas interpretativos, revelados pelo trabalho coletivo de gerações de estudiosos, que dará as melhores indicações sobre as circunstâncias e técnicas de sua composição.

\section{FILOLOGIA E A BUSCA PELO HOMERO ORIGINAL}

Nos séculos III e II, uma sequência de intelectuais que trabalharam na Biblioteca de Alexandria, especialmente Aristarco, mas também seu antecessor Zenódoto e seu sucessor Aristófanes de Bizâncio, se debruçaram sobre os versos de Homero. Os seus trabalhos principais eram: (1) produzir $\dot{\pi} \pi \mu \nu \eta \dot{\mu} \mu \alpha \tau$ ( ("comentários"), ou seja, analisar e comentar passagens que proporcionassem problemas de interpretação, além de explicar palavras e expressões já obscuras (lembrando que entre o receptor do período helenístico e o vocabulário homérico já existia uma distân-

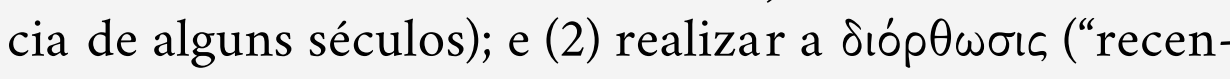
são"), ou seja, estabelecer o texto dos poemas homéricos, sem modernizações e sem versos acrescentados ao longo de sua transmissão, para produzirem uma edição (ह̋x de melhor qualidade. Provavelmente foram eles que fizeram a divisão dos dois poemas em vinte e quatro cantos, um para cada letra do alfabeto grego. Entre os principais materiais de trabalho dos bibliotecários de Alexandria estavam a xoเv'n, texto ou edição comum, possivelmente ateniense, e as $\pi 0 \lambda ı \tau i x \alpha i$, textos ou edições produzidas por cada cidade, como Quios, Argos, Chipre, Sínope e Massalia. 
Esses comentá rios nos chegaram a través dos escólios e de coleções desses escólios. $^{27}$

O trabalho dos bibliotecários de Alexandria inspirou a abordagem dos filólogos da escola analista, viés teórico predominante no mundo acadêmico europeu do século XIX. A partir do trabalho seminal de Wolf, Prolegomena ad Homerum, a figura de Homero como autor foi colocada em questão. Wolf já identificava a origem oral e tradicional da épica grega, a princípio um produto de cantores, não de escritores, uma vez que a própria tecnologia da escrita seria, na época da composição inicial dos poemas, inexistente ou incipiente. ${ }^{28}$ Sua proposta era de que, na Atenas do século VII, pequenas canções épicas diferentes teriam sido reunidas para formar os grandes poemas escritos. O que conhecemos não seria a tradição oral, mas uma colcha de retalhos de diversas canções antigas, continua mente transformada com correções e interpolações desde o século VII a té os alexandrinos, de modo que não existiria um Homero como a utor individual. A evidência histórica dos escólios e a a nálise estilística seriam os recursos para obter a edição mais autêntica, pura e original possível. ${ }^{29}$ Essas eram as ideias com as quais concordou a maior parte dos acadêmicos da época, superando em termos de aceitação a noção unitarista que se apegava a Homero como o gênio original grego, o pai da poesia, que sacou da natureza suas regras de composição. ${ }^{30}$

Em sua breve introdução à história dos estudos homéricos, Dodds (em texto originalmente publicado em 1968) resume as tendências dos a nalistas posteriores a Wolf a partir da obra de Eduard Meyer (Geschichte dês Altertums, vol. 2, 1893): consideravam cientificamente provado que os poemas atribuídos a Homero não eram trabalho de um indivíduo nem de um coletivo de artistas, mas o resultado da atividade de poetas que se estendeu ao longo dos anos, de modo que seria possível identificar os diversos estratos. ${ }^{31}$ No início do século XIX, a ideia básica era a de Gottfried Hermann, de que, a partir de um núcleo inicial, os poemas eram expandidos com acréscimos. ${ }^{32}$ No caso da Ilíada, em geral o poema preferido dos analistas, o núcleo seria este: a briga dos chefes (canto I), a derrota dos gregos (canto XI), a Patrocleia (canto XVI, com o fim do XV) e a morte de Heitor (ca nto XXII). Os trechos que fariam as transições originais entre cada parte desse núcleo não mais seriam recuperáveis. Fora disso, havia pouca concordância, exceto a respeito do trecho conhecido como Doloneia (canto X), da embaixada (canto IX), e da batalha no canto VIII, que seriam todos posteriores, assim como a inclusão no poema de personagens como Nestor, Glauco, Sarpédon e Eneias. Se, para os primeiros leitores de Wolf, Homero era apenas 
um nome dado à personificação do "espírito da poesia épica" ou a um ancestral mítico da guilda de bardos que se chamava de Homeridas, nesse segundo momento ele passa a ser o nome do autor histórico do poema original que corresponderia ao núcleo esboçado acima.

Ainda conforme a introdução de Dodds, uma geração posterior de analistas modificou ainda mais uma vez o mito de Homero, a partir do trabalho de Wila mowitz (Die Ilias und Homer, 1916). ${ }^{33}$ O poeta seria o homem natura de Quios que, no século VIII, combinou e remodelou o trabalho de vários poetas anteriores. Essa obra, por sua vez, seria ta mbém remodelada e aumentada pelas gerações de poetas posteriores. Agora, integra riam a Ilíada de Homero a "substância principal" dos cantos I a VII, XI a XVII e XXI a XXIII, até o enterro de Pátroclo (o final original estaria perdido, assim como a ligação entre os cantos XVII e XXI). Nas palavras de Schadewaldt (em texto de 1938 com vá rias reedições), então o "compilador inábil de um material original se tornou o poeta que costurou o poema a partir de retalhos tradicionais, dando-lhes uma estrutura de unidade". ${ }^{34}$

Para realizar esse tipo de análise, utilizava-se a crítica textual, as comparações estilísticas e uma leitura minuciosa do texto e da construção narrativa dos poemas, com o objetivo de avaliar as lições possíveis transmitidas pelos fragmentos em papiro, pela tradição de manuscritos medievais e pelos comentários antigos em busca de um entendimento da língua e do pensamento homéricos que permitisse identificar as irregularidades que deveriam ser extirpadas. ${ }^{35}$ Muitas vezes esses trechos teriam o próprio núcleo original como modelo de construção, o que ficaria visível em cenas que aparecem no poema mais de uma vez com texto idêntico ou só com pequenas diferenças e também em cenas que apresentam inconsistências de pensamento ou qualidade poética em comparação com o conjunto. Como observa Schadewaldt, o fato de que os bibliotecários alexandrinos marcavam os versos repetidos como espúrios, conforme a preferência estética do Período Helenístico, dava a esse procedimento um respaldo de aparente autoridade. ${ }^{36}$

No caso da Odisseia, ainda seguindo a retrospectiva de Dodds, o consenso a nalista era atribuir a obra a um autor diferente daquele da Ilíada, e muitos a consideravam uma composição de um único poeta. ${ }^{37}$ Entretanto, apesar da maior unidade estrutural em comparação com o poema de Aquiles, o poema de Odisseu teria mais inconsistências internas. As una nimidades entre os analistas eram aquelas que Aristarco já anotava: o canto XXIV e parte da Nékyia (a passagem de Odisseu pelos domínios de Hades no canto XI) seriam acréscimos posteriores. Também a Telemaquia 
(a aventura de Telêmaco: cantos I a IV, com o XV, o XVI e o início do XVII) era colocada em dúvida. Apesar de ter um núcleo básico composto pela viagem de retorno de Odisseu e a vingança contra os pretendentes, existiriam versões diferentes tanto das viagens quanto da vinga nça.

Ainda no século XIX, apesar de nunca se firmar como a vertente dominante entre os acadêmicos, o pensa mento unitarista recebeu formulações menos ingênuas, de modo a figurar como outra corrente importante de leitura e interpretação da construção do texto homérico. Como recupera Nagy, a partir dos trabalhos de Nitzsch (18261940; 1852), os unitaristas concebiam a Ilíada e a Odisseia como obras que têm uma unidade poética e narrativa, pensadas como um todo com suas partes intimamente conectadas e compostas por um único autor. ${ }^{38} \mathrm{Ou}$ seja, o que os a nalistas interpretavam como acréscimos ao texto, que deveriam ser extirpados, os unitaristas tentavam explicar como parte da dinâmica narrativa dos poemas. $\mathrm{O}$ trabalho filológico e a análise estilística dão lugar à crítica literária. Para Dodds, o movimento básico no fim do século XX é o desenvolvimento de um novo "jogo lógico", paralelo àquele velho jogo de tentar descobrir inconsistências em Homero: o de tentar explicá-las. Tentativas de desmontar as incongruências apontadas pelos analistas acompanhada por uma insistência em afirmar a originalidade de Homero deram lugar a unitaristas que não desprezava $m$ de todo os métodos e conclusões dos analistas. ${ }^{39}$ Aquilo que os analistas chamavam de "núcleo" e "expansões" foi assimilado pelos unitaristas como "fonte" e "interpolações".

\section{HOMERO COMO POESIA ORAL TRADICIONAL}

A trajetória dos estudos homéricos foi redefinida, entretanto, com os trabalhos de Milman Parry e Albert Lord. A partir do final dos anos 20 do século XX, Parry começa a publicar seus estudos sobre o estilo de Homero, primeiramente, com uma investigação sobre a estrutura métrica e o uso de adjetivos qualificando nomes de heróis e deuses, os epítetos que classificava como "orna mentais". As conclusões de Parry a partir dessa análise estilística formam a base do que foi chamado de "teoria oral", inicialmente ignorada ou recebida com resistência, mas posteriormente adotada como principal abordagem para o estudo dos textos homéricos. No trabalho de Wolf, já se pensava numa origem oral da tradição épica, mas agora ela faz parte da composição dos poemas de outra maneira, descoberta a partir de um escrutínio minucioso das repetições e va riações na construção dos versos homéricos e de sua comparação com a poesia épica oral tradicional servo-croata, ainda praticada na Iugoslávia antes da Segunda Guerra Mundial. ${ }^{40}$ Parry revela um Homero que compõe em estilo tradicional e adaptado à composição 
oral, sem a necessidade da escrita. ${ }^{41} \mathrm{~A}$ unidade básica da técnica de composição oral tradicional é a fórmula, definida como "um grupo de palavras usado regularmente sob as mesmas condições métricas para expressar uma dada ideia essencial”. ${ }^{42}$ Essas fórmulas compõem um sistema que fornece ao poeta um arsenal de formas tradicionais que se encaixam perfeitamente nas diversas posições do hexâmetro para cumprir a função sintática necessária para expressar determinado sentido.

Por exemplo, usando fórmulas formadas por um nome e um ou mais epítetos no nominativo, a ideia essencial

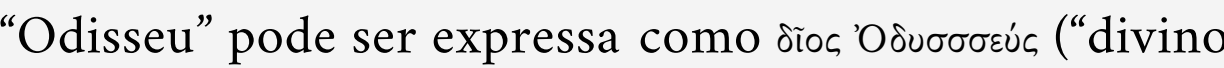

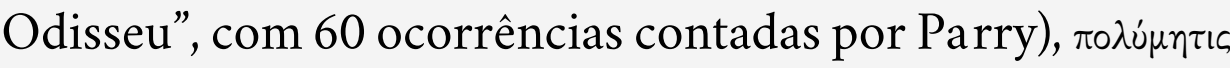

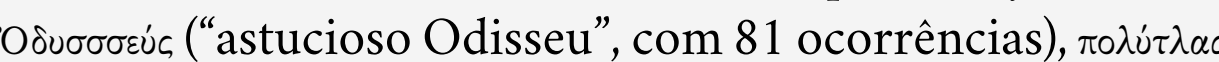

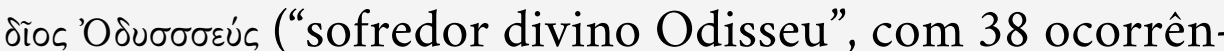

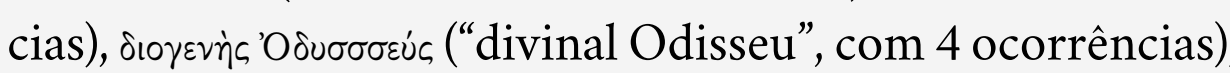
cada uma dessas com uma configuração métrica diferente. ${ }^{43}$

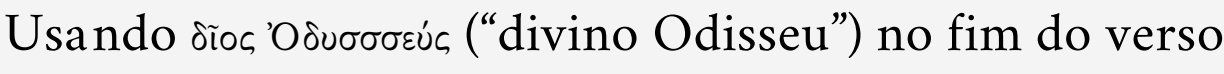
Parry lista treze exemplos em que essa fórmula é antecedida por um verbo, mostrando-se como um dos modelos para se indicar que Odisseu realizou determinada ação. ${ }^{4}$ Substituindo "divino Odisseu" por fórmulas homéricas que

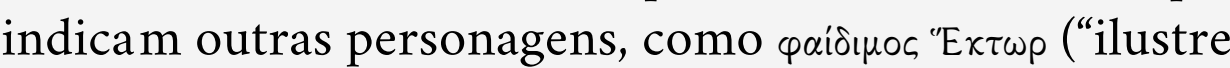

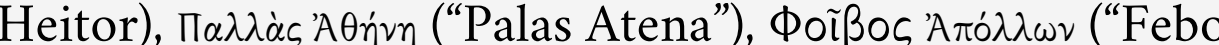

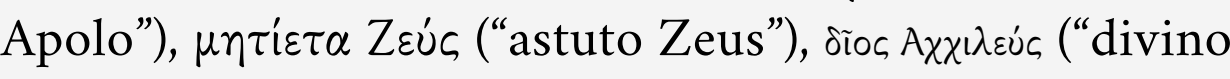

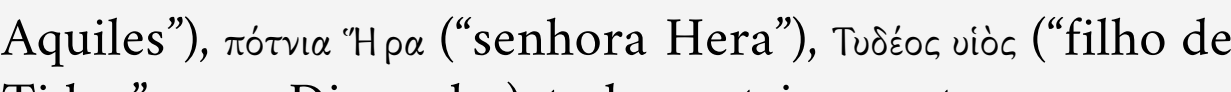
Tideu", para Diomedes), todas metricamente correspondentes, forma-se um padrão que ajuda a compor hexâmetros em que determinado personagem realiza determinada ação. ${ }^{45}$

O sistema é extenso, composto de muitas entradas abarcando grande variedade de ideias diferentes, mas ao mesmo tempo é econômico, com pouca repetição de entradas com ideias essenciais e configurações métricas idênticas. O recurso básico de composição é a analogia. Os poetas épicos mantinham fórmulas antigas e podia m também adaptá-las a diversos contextos ou mesmo criar novas fórmulas que, por sua vez, poderiam ser incorporadas por outros poetas. O som guiaria um poeta para a criação de fórmulas e para seu agrupa mento ${ }^{46}$ Nessa perspectiva da teoria oral, as repetições que ta nto incomodava $m$ os analistas ou mesmo os alexandrinos não indicam a expansão por cópia de uma ocorrência original. São, na verdade, a base técnica da construção textual. ${ }^{47}$

A fórmula é a unidade básica para a construção do verso, mas ainda era preciso entender seu uso na composição de longos poemas narrativos. Arend, sem partilhar da teoria oral de Parry, havia identificado nos poemas homéricos o uso da técnica que chamou de "cenas típicas". ${ }^{48}$ Quando comparadas, percebe-se que as cenas de determinados 
eventos básicos da narrativa - cenas de chegada sacrifício, refeição, jornada por mar ou terra, equipagem de armas, vestição de roupas, sono, hesitação antes de decisão ( $\mu \varepsilon p \mu \eta p i$ ¿દı), assembleia, jura mento e ba nho - são apresentadas repetidas vezes com praticamente os mesmos versos (ou ao menos idênticas partes de versos), de modo que, apesar de terem detalhes diferentes, usam uma mesma base ou moldura. Parry (em resenha originalmente publicada em 1936) observa que as cenas típicas demonstradas por Arend, "uma dicção fixa e um padrão típico para contar a história", revelam exatamente o modo como a poesia narrativa oral tradicional é composta. ${ }^{49} \mathrm{~A}$ ideia é desenvolvida por Lord, que estuda essa técnica de construção narrativa em Homero e na tradição oral servo-croata. Ele chama de "tema" ou "composição temática" aquilo que define como um elemento recorrente da narrativa ou descrição na poesia oral tradicional, não restrito por considerações métricas e, portanto, não limitado à repetição palavra por palavra. ${ }^{50}$ Como exemplo, apresenta três cenas de banquete: ${ }^{51}$

Para eles os arautos vertiam água nas mãos, e pão as escravas, à frente, a montoavam em cestas, e moços preencheram ânforas com bebida

e a todos distribuíam após verter as primícias nos cálices].

E eles esticavam as mãos sobre os alimentos servidos.

Mas após apaziguar o desejo por bebida e comida, os pretendentes [...] (Odisseia, I, 146-15)

para eles os arautos vertiam água nas mãos,

e moços preencheram ânforas com bebida

e a todos distribuíam após verter as primícias nos cálices.

As línguas lançavam ao fogo, e de pé sobre elas libavam.

Mas depois de libar e beber quanto quis o ânimo, (Odisseia,

III, 338-42)

\section{Para eles os arautos vertiam água nas mãos,}

e moços preencheram ânforas com bebida

e a todos distribuíam após verter primícias nos cálices.

Mas depois de libar e beber tudo que quis o ânimo, (Odisseia, XXI, 270-3) ${ }^{52}$

Não são grupos idênticos, mas compartilham elementos básicos (pode-se observar que em todas estão presentes os atos de lavar as mãos, servir a mesa, distribuir a bebida fazer libações e saciar-se) que podem aparecer de forma mais sintética ou mais expandida. No testemunho de um poeta iugoslavo sobre o modo como aprendia uma nova canção, ele não tenta memorizar com exatidão todas as palavras da canção, mas aprende o "plano" dessa canção. ${ }^{53}$ Ou seja, com a estrutura narrativa em mente, o poeta desenvolve os temas a partir das formas tradicionais de contar cada um deles e conforme o apropriado para a 
parte da história que está narrando. ${ }^{54}$ É a composição em performance que também Parry já propunha.

Em seu livro originalmente publicado em 1960, Lord, que foi assistente de Parry, se detém com mais atenção nesse modo de composição que o aedo da épica grega arcaica compartilha com o guslar da épica oral servo-croata. A composição em performance não é o mesmo que composição para performance. $\mathrm{O}$ cantor de casos, apresentando-se em locais públicos ou particulares, compõe respondendo diretamente a uma audiência variável e instável, podendo alongar ou encurtar a apresentação de sua canção (valorizando os detalhes e descrições, por exemplo) conforme a receptividade da audiência. ${ }^{55}$ Enquanto treina suas habilidades de composição, o poeta vai aprendendo a expandir canções a ponto de poder entreter uma audiência por uma noite inteira e, num estágio final, domina um repertório para sustentar diversas noites de canto em apresentações com tamanho e grau de ornamentação sempre dependentes das demandas da audiência. ${ }^{56}$

A tradição oral tem conceitos diferentes de estabilidade e mudança. Consequentemente, tem ta mbém um conceito diferente de "canção". A ideia de estabilidade parece importante para o poeta, mas não inclui "o palavreado exato, que para ele nunca se fixou, nem as partes não essenciais da história". ${ }^{57}$ Quando um poeta apresenta uma história conhecida com seu próprio estoque de fórmulas, temas e sua técnica de composição, ele constrói sua performance única (que seria uma "canção" no sentido usado num sistema literário letrado) a partir do esqueleto narrativo (que seria a "canção" no sistema oral tradicional). Na tradição oral, o conceito de "original" não se aplica. Cada canção é diferente na medida em que cada performance particular de cada cantor é única (um ato de criação, não de reprodução), embora permaneça a mesma canção, com sua ideia fundamental característica. Assim, "O casamento de Smailagić Meho" é a canção que narra a aventura desse herói e uma performance específica de O casamento de Smailagić Meho foi ditada por Avdo Međedović em julho de $1935 .^{58}$

\section{REFINANDO A ORALIDADE DE HOMERO}

$O$ funcionamento do sistema de fórmulas que funda menta a teoria oral atraiu a atenção de pesquisadores e foi mais estudado, principalmente nas décadas de 60 e 70 do século XX, com continuidade que se estende ao início do século XXI. Nesse processo, a própria definição de fórmula feita por Parry foi posta em questão. Notopoulos cha mou a tenção para o uso de estruturas sintáticas analógicas, não só de repetições de blocos idênticos demonstrados por Parry e definidos como fórmulas ${ }^{59} \mathrm{~A}$ observação de certa flexibilidade dos componentes do verso na poesia oral fez Russo (em trabalho de 1963 reconsiderado em 1997) propor 
uma espécie de "fórmula estrutural", ou seja, estruturas linguísticas abstratas ou matrizes a partir das quais as fórmulas seriam geradas. $\mathrm{O}$ problema, como ele admite posteriormente, é que as fórmulas estruturais, por terem uma definição muito vaga, perdem seu caráter decisivo como indicadores da origem oral dos poemas. ${ }^{60}$

Também pensando na flexibilidade da fórmula, mas recusando as matrizes, Hainsworth propõe a definição de fórmula como "um grupo de palavras repetido em que o uso de uma palavra criou uma forte antecipação de que outra seguiria”. ${ }^{61}$ Abandonando as condições métricas por essa espécie de relação tradicional entre palavras, as possibilidades de mudança e adaptação de fórmulas incluíam a mobilidade na posição do verso, a expansão, a separação das palavras, o uso de substantivos em outros casos ou outros ajustes. ${ }^{62}$ Hoekstra, seguindo uma linha parecida mostrou o que chamou de "modificação de protótipos formula res": o efeito de flexibilização da dicção épica exercido por inovações linguísticas, como a inversão de qua ntidade de vogais (metátese quantitativa), a queda da pronunciação do antigo fonema consonantal $w$ (o diga ma), a introdução do $-v$ móvel opcional e o uso de novas versões de formas arcaicas de qualquer tipo ${ }^{63}$ Foi a primeira prova de que a presença de elementos linguísticos mais recentes não precisa ser marca de uma interpolação posterior. É o uso de inovações da linguagem para a mpliar as possibilidades de escolhas e assim facilitar a composição poética. ${ }^{64} \mathrm{Nagler}$ tentou lidar com a flexibilidade da fórmula com uma perspectiva teórica mais abstrata. Propôs que o mecanismo básico de geração de fórmulas seria uma "Gestalt pré-verbal", ou seja, um modelo na mente do poeta. ${ }^{65}$ Aquilo que o poeta verbaliza seria um "alomorfo", a realização no momento de enunciação desse modelo mental abstrato. ${ }^{66}$ Os rígidos blocos de Parry, apesar de provarem a oralidade característica da poesia homérica, não explicam a variedade de recursos usados na construção dos versos conforme o estilo oral. Mesmo Lord já assumia uma maior flexibilidade no sistema de fórmulas: mais importante que cada fórmula específica eram os padrões sintáticos que possibilitavam a criação de novas fórmulas por analogia (ou seja, com substituições e ajustes). ${ }^{67}$

Uma discussão paralela acontecia a respeito dos aspectos semânticos da fórmula na composição oral. Um primeiro efeito da identificação da oralidade da poesia homérica foi uma abordagem, como a de Combellack, do uso das fórmulas na construção de versos como mera conveniência métrica, sem sentido especial ou apropriado para cada passagem..$^{68} \mathrm{O}$ conhecimento sobre o estilo oral dos poemas homéricos vinha sendo refinado, mas, como efeito colateral, as discussões sobre estilo e composição foram dominadas 
pela gramática e pela métrica, deixando de lado a leitura do poema como obra de arte e a utilização de recursos poéticos para causar um efeito estético. ${ }^{69}$ Entretanto, considerando ainda a escala mínima da fórmula, Whallon (em trabalhos de 1961 e 1979) mostrou como, por exemplo, epítetos são usados de forma apropriada para certos heróis, comparando adjetivos com esquemas métricos idênticos e sentidos diferentes, de modo que pesavam significa tivamente na caracterização desses personagens..$^{70}$ De forma complementar, Griffin mostra as diferenças entre os vocabulários do narrador e dos discursos de personagens e também entre discursos de diferentes personagens, de modo que não formam um sistema mecânico e engessado, mas respondem a uma liberdade de escolha para formar aquilo que se está compondo conforme as necessidades e interesses de cada contexto narrativo. ${ }^{71}$ É também a forma como Austin entende a composição formular, com cada elemento escolhido pelos dados semânticos que traz, com os adjetivos, por exemplo, especializando os substantivos, ou seja, incluindo informação na caracterização daquilo que determinam. ${ }^{72}$ As diferenças entre as expressões de cada personagem revelam a relação que têm com aquilo que falam e se adequam ao contexto a cada caso. ${ }^{73}$ Os pretendentes, por exemplo, nunca usam epítetos que indicam a inteligência de Odisseu,

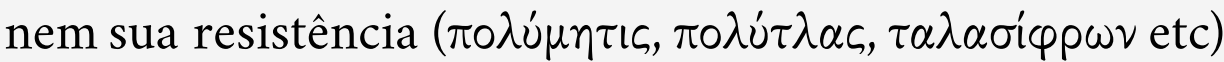
ao contrário de Haliterses, partidário da família de Odisseu em Ítaca, que, em sua previsão diante da assembleia no canto II, 173 , se refere ao herói como $\pi 0 \lambda u ́ \mu \eta \tau \iota .^{74}$

Após essas ondas dos anos 60 e 70, estudiosos tentaram lidar tanto com a flexibilidade da fórmula e seu funcionamento quanto com as relações semânticas que ela sugere na construção do texto. Para Visser (originalmente publicado em 1988) a fórmula não é uma unidade fixa dada, mas um composto de dois elementos: (1) um núcleo semântico que representa a necessidade de sentido conforme o contexto e (2) uma estrutura prosódica que facilita a composição e adapta o núcleo semântico à métrica de formas variadas e opcionais. ${ }^{75}$ Sua proposta se aproxima daquela dos primeiros intérpretes de Parry, quando diminui a importância semântica de certas variações que o estilo formular permite e privilegia a possibilidade de que um mesmo sentido possa ter várias formatações métricas diferentes. Entretanto, se afasta deles quando não identifica a fórmula como apenas um bloco de palavras: o poeta pensa em palavras (não em blocos) e seu texto pode ser interpretado como o de qualquer poeta. No a no seguinte, avaliando o texto dos poemas sob a perspectiva da variação, Finkelberg (1989) e Sale (1989) chegaram à curiosa conclusão de que os textos têm $70 \%$ de dicção formular e 30\% de uma mistura indeterminável de expressão livre e fórmulas menos representativas. ${ }^{76}$ 
Pontos de vista um pouco mais recentes têm como diferencial estudar a fórmula e o estilo oral através da análise do discurso. Na descrição de "estilo formular" dada por Zumthor (originalmente publicado em 1983) o discurso já estava presente:

Mais do que um tipo de organização, este estilo pode ser descrito como uma estratégia discursiva e intertextual: o estilo formular se encastra no discurso, à medida que se desenvolve, e integra, funcionalizando-os, fragmentos rítmicos e linguísticos tomados de outros enunciados preexistentes, em princípio pertencendo ao mesmo gênero, e levando o ouvinte a um universo semântico que lhe é familiar. ${ }^{77}$

Bakker parte dos estudos sobre o discurso para inverter o modo de avaliar a oralidade em relação à escrita. Isso porque "poesia oral" parte da perspectiva letrada, colocando a poesia escrita como membro privilegiado da dupla (ou "a norma”). Sua perspectiva é da oralidade como forma básica da linguagem e a sintaxe da escrita como o caso especial. ${ }^{78} \mathrm{~A}$ observação do discurso falado típico mostra que ele é constituído por unidades de sentido (palavras ou expressões que formam uma unidade) mais frequentemente tradicionais do que originais. As unidades básicas do discurso poético são em geral muito mais sintéticas do que as do discurso comum, então a poesia é a estilização das unidades de sentido da fala comum. A fórmula, como unidade de sentido primária do discurso homérico, não o distingue da poesia escrita, mas do discurso comum. ${ }^{79}$ Então também não pode ser o que separa o discurso épico do discurso de outros gêneros poéticos: na verdade, as fórmulas derivam da natureza cognitiva da linguagem falada. ${ }^{80}$ Quanto aos componentes textuais, Bakker ta mbém trabalha com a distinção de um núcleo de sentido com seus elementos periféricos. ${ }^{81}$

Já foi aqui mencionada a composição em performance como característica da poesia épica oral desde os estudos de Parry e Lord. Kirk estipula que no período arcaico as apresentações poderiam acontecer em cortes de aristocratas (como indica a posição de Fêmio e Demódoco na Odisseia), em concursos realizados em ocasiões específicas (Trabalhos e Dias, 654-782), em festivais religiosos e em espaços em que alcançassem audiências populares, sejam eles privados, como uma casa e uma taverna, ou públicos, como uma praça, um mercado. ${ }^{83}$ Os possíveis indícios disso na Odisseia seriam dois: o aedo (åoióc) faz parte da classe dos

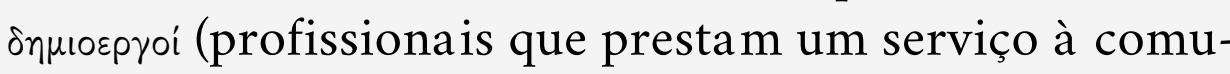
nidade, Odisseia, XVII, 382-5), e o aedo Demódoco (cujo nome, $\Delta \eta \mu$ óoxoc, pode ser formado pelas mesmas raízes de $\delta \tilde{\eta} \mu \circ$ e $\delta \varepsilon_{\chi} \chi \mu \alpha \mathrm{l}$, dando o sentido "recebido pelo povo", que Kirk desdobra para "agradável para o povo ou aceito pelo

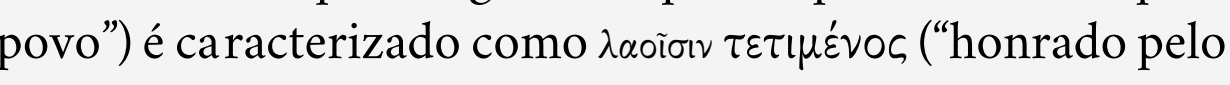


povo", Odisseia, XIII, 28). A performance do poeta, além do espetáculo poético, é "um evento cultural que conecta as pessoas de uma comunidade com seu passado" ${ }^{84}$

A transposição desse tipo de performance para o texto escrito é outro objeto de investigação ${ }^{85}$ Isso poderia ter acontecido de modo semelhante àquele como Parry e Lord registraram a poesia épica servo-croata: a transcrição de uma performance especial ou um "texto oral ditado". Janko, sem muitos argumentos, imagina que seria mais fácil esse projeto ser empreendido por um colecionador ou patrono, talvez movido por motivos ideológicos, do que como projeto pessoal de um poeta que quisesse passar para o papel sua canção. ${ }^{86}$ Entretanto, embora a escrita possa formar um texto que a partir de então pode ser memorizado e retransmitido oralmente, ela não necessaria mente encerra o sistema de composição em performance. Conforme a proposta de Nagy, a fixação do texto é um processo, não um evento. ${ }^{87}$ Nesse processo evolutivo, a tradição épica homérica vai se tornando cada vez menos fluida e mais rígida em seus padrões de recomposição. As primeiras versões escritas seriam apenas transcrições particulares, não edições standard ou modelos para outras performances. Na hipótese imaginada por Nagy, o processo (ou o "modelo evolucionário") teria cinco estágios: ${ }^{88}$
1. um período relativamente mais fluido, sem texto escrito, estendendo-se do início do segundo milênio até a metade do século VIII do primeiro milênio.

2. um período formativo ou "pan-helênico", ainda sem texto escrito, da metade do século VIII até a metade do VI.

3. um período definitivo, centralizado em Atenas, com potencia is textos escritos no sentido de transcrições [textos que podem ser registros de performance ou uma ajuda para performance, mas não o equivalente a uma performance], em qualquer ponto ou em muitos pontos da metade do século VI até a segunda parte do IV; esse período começa com a reforma das tradições de performance homérica em Atenas durante o regime dos Pisistrátidas.

4. um período de padronização, com textos no sentido de transcrições ou mesmo de scripts [texto que é pré-requisito para uma performance], da segunda parte do século IV até a metade do século II; esse período começa com a reforma das tradições de performance homérica em Atenas com o regime de Demétrio de Fálero, que dura de 317 a 307.

5. um período relativamente mais rígido, com textos como escritura [texto que não pressupõe uma performance], da metade do século II em diante; esse período começa com a finalização do trabalho editorial de Aristarco nos textos 
homéricos, não muito depois de 150 aproximadamente, que é a da ta que também marca o desaparecimento gera dos papiros chamados de "excêntricos" ${ }^{89}$

Mesmo que os estágios possam ser questionados, o modelo geral de difusão do texto com progressiva "cristalização" não é totalmente inverossímil. Nagy parte dos estudos de Pickens (1978) sobre a canção medieval e, principalmente, do conceito de "movência" (mouvance), a recomposição em performance que garante a continuidade do poema na tradição através da variação, para propor o mesmo modelo na transmissão e estabelecimento dos poemas homéricos. As edições dos poemas homéricos, portanto, necessita ria m do mesmo formato multitexto usado em algumas edições de poesia medieval. Esse formato abarca as variações possíveis próprias do estilo oral. A edição multitextual não incluiria os erros de cópia e acidentes de transmissão, mas apenas as variantes autênticas da tradição oral, que estariam disponíveis para os bibliotecários alexandrinos, nas diferentes edições que conseguiam obter de toda parte do mundo helenístico. A essas variantes que ainda circulavam nesse período só temos acesso pelas indicações dos escólios. No entendimento de Nagy, então, as correções dos bibliotecários de Alexandria não são conjecturas, mas escolhas de edição que revelam variações autênticas da performance oral multiforme. ${ }^{90}$ As variantes autênticas, ou seja, em conformidade com a dicção épica tradicional, seriam o ma terial base para uma edição multitextual que está sendo editada atualmente por Casey Dué e Mary Ebbott (no Center for Hellenic Studies) com participação de diversos especialistas, sobretudo, dos Estados Unidos. ${ }^{91}$

A teoria oral de Parry, primeiramente bem recebida no mundo anglófono e depois aceita por estudiosos de toda parte, entretanto, nunca foi uma unanimidade. Com a teoria oral, os fundamentos e métodos da corrente analista fora $\mathrm{m}$ sendo questionados com o tempo, mas, ao longo do século XX, desenvolveu-se paralelamente outro modo de trabalhar os poemas homéricos. Nos anos 30 do século XX, Bowra já dizia que a contenda intelectual entre analistas e unitaristas resultou em um consenso: de que os poemas que conhecemos resultaram de um trabalho de um poeta único lidando com material tradicional. ${ }^{92}$ Assim, outra vertente de estudos homéricos surgiu ainda no século XX, os neoanalistas, que, apesar do nome herdado dos antigos a nalistas, não retomam a antiga perspectiva de textos compilados. Conforme a exposição teórica de Kullmann (originalmente publicada em 1984), eles consideram os poemas como unidades produzidas por um poeta utilizando a tradição épica oral, mas já produzindo com o auxílio da escrita e com um elevado gra de criação individual..$^{93}$ A perspectiva é de que certos motivos que aparecem nos poemas homéricos teriam 
sido tomados de outros poemas da tradição oral (os poemas que compõem o "ciclo épico" arcaico que seriam posteriormente ta mbém registrados por escrito $\left.{ }^{94}\right)$. Esses outros poemas do sistema de produção e propagação da poesia oral influenciariam a construção da Ilíada e da Odisseia e, em muitos casos, as fontes de certos recursos e motivos seriam identificáveis.

O próprio Kullmann admite que não é necessário que as duas teorias (a oral e a neoanálise) sejam mutuamente excludentes. Estudiosos que partem de uma perspectiva oralista e consideram a relação dos poemas com a tradição puderam identificar, por exemplo, como a narrativa da Ilíada faz referências a eventos mitológicos que seriam parte de outros épicos, e como ela cria suas próprias cenas a partir de eventos marcantes desses outros poemas, em parte para se destacar entre eles como o grande poema épico ${ }^{95}$ ou sugerir como a Odisseia constrói um retorno de Odisseu que nega outras possíveis versões que circulariam, talvez como tradições locais de determinadas regiões. ${ }^{96}$ Entretanto, mais do que relações entre poemas específicos, talvez o que caracterize a composição épica seja a relação do poema, do poeta e da audiência com a tradição.

\section{REFERENCIALIDADE TRADICIONAL E RESSONÂNCIA}

A interdependência entre o poeta e a tradição poética é o foco de uma perspectiva oralista mais recente, em que o conceito de "referencialidade tradicional" (nas palavras de Foley em trabalhos de 1997 e 1999) ${ }^{97}$ ou "ressonância" (na formulação de Graziosi e Haubold no trabalho de 2013 ${ }^{98}$. A proposta de Foley era atualizar a teoria oral para evitar simplificações excessivas incompatíveis com a complexidade dos textos, para responder as ressalvas de seus críticos e para explicar como os textos homéricos são compostos não "apesar da tradição oral”, mas por seu funcionamento e suas possibilidades. ${ }^{99}$ A expressão épica oral grega arcaica funciona sempre diante do pano de fundo da tradição. A linguagem especial da poesia no contexto especial de sua performance faz com que a audiência sempre situe a canção, uma passagem e certas expressões em conexão com seus usos tradicionais. Isso é o que Foley chama de "refencialidade tradicional". A expressão

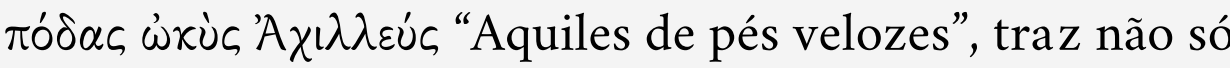
a ideia essencial de "Aquiles”, mas uma caracterização que concentra sua representação heroica e sua história mítica. ${ }^{100}$ Nesse processo, a audiência tem o papel de completar o "circuito da comunicação" ${ }^{101}$ As fórmulas, os padrões narrativos e outras unidades expressivas são sinais potencialmente repletos de implicações. ${ }^{102}$ 
Kelly também ajuda na compreensão do aspecto referencial da tradição oral e enfatiza que poeta e tradição são interdependentes. A elucidação da poesia homérica deve levar em conta sua estética da repetição faz com que o contexto seja profundamente significativo. $\mathrm{O}$ potencia referencial é realizado pela habilidade do poeta e pela interpretação da audiência de temas que aparecem no curso de uma narrativa dinâmica. ${ }^{103} \mathrm{O}$ poeta oral e sua audiência conhecem um "arcabouço poético [...] composto por um número grande, mas finito, de unidades repetidas [... desenvolvido e transmitido por um número grande, mas igualmente finito, de poetas". ${ }^{104}$

Graziosi e Haubold continuam a atualização da teoria oral, chamando de "ressonância", a habilidade de evocar a mais a mpla tradição épica e se colocar em relação a essa tradição vasta e coerente, que abarca a história do mundo, das origens ao presente. ${ }^{105}$ As ressonâncias temáticas, linguísticas e estilísticas perpassam a poesia homérica em todos os níveis, de modo que os poemas se apresentam como parte de uma narrativa mais a mpla. ${ }^{106}$ Expressões que se repetem, como “Aquiles de pés velozes" disparam uma cadeia de associações mentais na audiência, às vezes ressoando em harmonia, como quando Aquiles volta para o campo de batalha, às vezes em dissonância, como quando Aquiles está fora de combate, em sua tenda. Dessa forma, elas encapsulam a essência de personagens, ações e histórias particulares e, junto com todo tipo de padrão repetido, combinam-se de modo a ajudar a entender e situar uma cena dentro do contexto geral da tradição. ${ }^{107}$

Essa ressonância ou referencialidade tradicional explica melhor os procedimentos de composição e recepção da audiência no sistema literário oral. O poeta compõe a partir de um repertório de histórias, temas e expressões que compartilha com seu público e que serão interpretados levando em consideração a articulação entre as passagens, o poema como um todo e o contexto no repertório épico oral.

\section{CONCLUSÃO}

Por fim, sobre Homero, é possível concorda r com Malta: "é a tradição múltipla e móvel - que anda de mãos dadas, é bom ressaltar, com a invenção poética - que elabora um 'Homero', e não Homero que elabora a tradição múltipla e móvel, ainda que um Homero de carne e osso possa ter existido e ter mesmo sido um grande rapsodo". ${ }^{108}$ Brandão observa que para os gregos Homero nada mais é que o narrador dos poemas homéricos, ${ }^{109}$ mas talvez seja melhor entender "Homero" como um modo de se referir à Ilíada e à Odisseia, e como quem controla o narrador e, assim, escolhe a disposição dos elementos significativos no texto. $\mathrm{Na}$ ausência de uma biografia, Homero torna-se esse próprio 
controle e essa própria disposição. A partir de todas essas reflexões sobre Homero e as diferentes interpretações que seu estilo recebeu ao longo da história da Filologia e dos Estudos Literários, uma perspectiva razoável, em termos de estra tégias de leitura e interpretação, é reconhecer a interdependência entre poeta e tradição, aceitar as variações da fórmula e da técnica oral e, sem nenhuma certeza quanto ao ca minho que levou um texto da tradição oral para a tradição escrita, ler os poemas homéricos como poesia e como narrativas que formam uma unidade, compostas por palavras que, por sua vez, constituem versos de um poema com seus componentes sonoros, imagéticos e semânticos significativos.

\section{REFERÊNCIAS}

\section{EDIÇÕES DE TEXTOS GREGOS}

DIELS, Hermann (ed.). Die Fragmente der Vorsokratiker: Griechisch und Deustch von Hermann Diels; Zehnte Auflage herausgegeben Von Walter Kranz. 10. Aufl. 3 vols. Berlin: Weidmannsche Verlagsbuchandlung, 1960-61.

DIOGENES LAERTIUS. Lives of Eminent Philosophers: Edited with Introduction by Tiziano Dorandi. Cambridge: Cambridge University Press, 2013.
DRACHMANN, A. B (ed.). Scholia vetera in Pindari carmina. 3 vols. Leipzig: Teubner, 1903-27.

HOMERI Ilias: (3 vols.) edidit T. W. Allen. Oxford: Clarendon Press, 1931

HOMERI Odyssea: Recognovit Helmut van Thiel. Hildesheim: Georg OlmsVerlag, 1991.

HESIODI. Theogonia, Opera et Dies, Scutum: Edidit Friedrich Solmsen. Oxford: Oxford University Press, 1970.

HUMBERT, J (ed.). Hymnes Homériques. Paris: Les Belles Lettres, 1936.

PINDARI. Carmina cum fragmentis: Edidit H. Maehler (post B. Snell). Leipzig: Teubner, 1971.

PLATON. Oeuvres complètes: Texte établi et traduit par Maurice Croiset et al. 4 ed. rev. et cor. Paris: Les Belles Lettres. 19-

STRABON. Geographie: Texte établi et traduit par Germaine Aujac. 9 vol. Paris: Les Belles Lettres, 1966-

TUCYDIDE. La guerre du Peloponnese: Texte établi et traduit par Jacqueline de Romilly. 5 vols. Paris: Les Belles Lettres, 1968-

WEST, Martin Litchfield (ed.). lambi et elegi Graeci ante Alexandrum cantata: edidit M. L. West. 2. ed. aucta atque emendata. 2 vols. Oxford: Oxford University Press, 1992.

XENOPHON. Banquet; Apologie de Socrate: Texte établi et traduit par Fançois Ollier. Paris: Les Belles Lettres, 1995. 


\section{TRADUÇÕES DE TEXTOS GREGOS}

ARISTÓTELES. Poética: Tradução, prefácio, introdução, comentário e apêndices de Eudoro de Sousa. Lisboa: Imprensa Nacional-Casa da Moeda, 2010.

HESÍODO. Trabalhos e Dias: Tradução e introdução: Christian Werner. São Paulo: Hedra, 2013.

HOMERO. Odisseia. Tradução de Christian Werner. São Paulo: Cosac \& Naify, 2014

SANTORO, Fernando. Filósofos Épicos I Parmênides e Xenófanes: fragmentos. Rio de Janeiro: Hexis / Fundação Biblioteca Nacional, 2011.

SILVA, Martim Reyes da Costa. Densidade Semântica e Jogos de Linguagem nos Fragmentos de Heráclito de Éfeso. 111 p Dissertação (Mestrado). Faculdade de Letras da Universidade Federal de Minas Gerais, 2013.

RIBEIRO Jr., Wilson Alves (org.). Hinos Homéricos: Tradução notas e estudo. São Paulo: Editora UNESP, 2010.

ESTUDOS

AREND, W. Die typische Scenen bei Homer. Berlin: Weidmann 1933

AUSTIN, Norman. Archery at the Dark of the Moon. Berkeley: University of California Press, 1975.
BAKKER, Egbert J. The Study of Homeric Discourse. In: MORRIS, lan: POWELL, Barry (eds) A New Companion to Homer Leiden: Brill, 1997, 284-304.

BAKKER, Egbert J. Introduction: Homer and Oral Poetry

Research. In: DE JONG, J. F. (ed.) Homer: Critical Assessments: vol. I - The Creation of the Poems. London: Routledge, 1999, p. $163-180$

BIRD, Graeme D. The Ptolemaic Papyri of the lliad: Evidence of Eccentricity or Multitextuality?. In: Pointing at the Past: From Formula to Performance in Homeric Poetics. Hellenic Studies Series 43. Washington: Center for Hellenic Studies, 2010.

BOWRA."Tradition and Design". In: DE JONG, J. F. (ed.) Homer: Critical Assessments: vol. I - The Creation of the Poems.

London: Routledge, 1999, p. 47-66.

BRANDÃO, Jacyntho Lins. Antiga Musa: (arqueologia da ficção). Belo Horizonte: Faculdade de Letras da UFMG, 2005.

BURKERT, Walter. The Orientalizing Revolution: Near Eastern Influence on Greek Culture in the Early Archaic Age. Translated by Margaret E. Pinder and Walter Burket. Cambridge: Harvard University Press, 1995.

DODDS, Eric Robertson. Introduction: Homer. In: DE JONG, J. F. (ed.) Homer: Critical Assessments: vol. I - The Creation of the Poems. London: Routledge, 1999, p. 3-16. 
DOURADO-LOPES, Antonio Orlando O. Natureza dos deuses e divindade da natureza: reflexões sobre a recepção antiga e moderna do antropomorfismo divino grego. Kriterion, v. 51, p. 377-397, 2010.

EDWARDS, Mark W. Type-Scenes and Homeric Hospitality Transactions of the American Philological Association. v. 105 1975, p. 51-72.

EDWARDS, Mark W. Homeric Style and Oral Poetics. In: MORRIS, lan; POWELL, Barry (eds.) A New Companion to Homer. Leiden: Brill, 1997, p. 261-283.

FOLEY, John Miles. Oral Tradition and its Implication. In: MORRIS, Ian; POWELL, Barry (eds.) A New Companion to Homer. Leiden: Brill, 1997, p. 146-73.

FOLEY, John Miles. Homer's Traditional Art. University Park: Pennsylvania State University Press, 1999

FOLEY, John Miles. "Reading" Homer though Oral Tradition. College Literature, v. 34, n. 2, 2007, p. 1-28

GRAZIOSI, Barbara; HAUBOLD, Johannes. Homer: the Resonance of Epic. London: Bloomsbury Academic, 2013.

HASLAM. Michael. Homeric Papyri and the Transmission of the Text. In: MORRIS, lan; POWELL, Barry (eds.) A New Companion to Homer. Leiden: Brill, 1997, p. 55-100.

HOEKSTRA, A. Epic Verse Before Homer. Amsterdam: NorthHolland Publishing Company 1981.
JANKO, Richard. The Homeric Poems as Oral Dictated Texts. Classical Quarterly, v. 48, n. 1, 1998, p. 135-167.

KELLY, Adrian. A Referential Commentary and Lexicon to Homer, lliad VIII. Oxford: Oxford University Press, 2007, p. 1-17.

KELLY, Adrian. Tradição na Épica Grega Antiga. Letras Clássicas , v. 14,2010 , p. 3-20

KIRK, G. S. The Circumstances of Monumental Composition. In: DE JONG, J. F (ed ) Homer: Critical Assessments: vol I - The Creation of the Poems. London: Routledge, 1999, p. 256-272.

KULLMANN, Wolfgang. Oral Poetry and Neoanalysis in Homeric Research. In: DE JONG, J. F. (ed.) Homer: Critical Assessments: vol. I - The Creation of the Poems. London: Routledge, 1999, p. $145-160$

LAMBERTON, Robert. Homer in Antiquity. In: MORRIS, lan; POWELL, Barry (eds.) A New Companion to Homer. Leiden Brill, 1997, p. 33-54

LORD, Albert. Composition by Theme in Homer and Southslavic Epos. Transactions of American Philology Association, v. 82 1951, p. $71-80$

ORD, Albert. The Singer of Tales. $2^{\text {nd }}$ edition, $4^{\text {th }}$ print. Atheneum: New York, 1971

LOUDEN, Bruce. Homer's Odyssey and the Near East Cambridge: Cambridge University Press, 2011. 
MAHLER, Anthony. Did Philologists write the lliad?: Friedrich August Wolf's criteria of style and the demonstrative power of citation. Möglichkeiten und Grenzen der Philologie: Tagungsband; 1. - 3. Juli 2010, Freie Universität Berlin, Internationale Arbeitstagung. Berlin: Friedrich Schlegel Graduiertenschule für literatur-wissenschaftliche Studien, 2013, p. 185-194.

MALTA, André. Homero Múltiplo. São Paulo: Editora da Universidade de São Paulo, 2012.

MARKS, Jim. Zeus in the Odyssey. Cambridge: Harvard University press, 2008

NAGY, Gregory. The Best of the Achaeans: concepts of the hero in archaic Greek poetry. Baltimore: The John Hopkins University Press, 1979.

NAGY, Gregory. Homeric Questions. Transactions of the American Philological Association, v. 122, 1992, p. 17-60.

NAGY, Gregory. Poetry as Performance. Cambridge: Cambridge University Press, 1996.

NAGY, Gregory. Homer's Text and Language. Urbana: University of Illinois Press, 2004.

PARRY, Milman. Studies in the Epic Technique of Oral VerseMaking. 1. Homer and Homeric Style. In: PARRY, Milman. The Making of Homeric Verse: The collected papers of Milman Parry. Edited by Adam Parry. Oxford: Clarendon Press, 1971, p. 266-324. Fixed Epithet. In: PARRY, Milman. The Making of Homeric Verse: Oxford: Clarendon Press, 1971, p. 37-117.

PARRY, Milman. On Typical Scenes in Homer. In: PARRY, Milman The Making of Homeric Verse: The collected papers of Milman Parry. Edited by Adam Parry. Oxford: Clarendon Press, 1971, p. 404-7.

REYNOLDS, L. D.; WILSON, N. G. Scribes and Scholars: A Guide to the Transmission of Greek and Latin Literature. 3rd. edition. Oxford: Oxford University Press, 1991.

PUCCl, Pietro. The Proem of the Odyssey. The Song of the Sirens. Lanham: Rowman \& Littlefield Publishers, 1998, p. 11-29.

RICHARDSON, Nicholas J. Homeric Professors in the Age of the Sophists. Proceedings of the Cambridge Philological Society, $v$ 21,1975, p. $65-81$

ROUSSEAU, Philippe. L'intrigue de Zeus. Europe, v. 79, n. 865 , 2001, p. 120-158

RUIJGH, C.J. D'Homère aux origines proto-mycéniennes de la tradition épique. Analyse dialectologique du langage homérique avec un excursus sur la création de l'alphabet grec. In:

CRIELAARD, J. P. (ed.) Homeric Questions: Essays in Philology, Ancient History and Archaeology. Amsterdam: Brill, 1995, p. 1-96.

RUSSO, Joseph. The Formula. In: MORRIS, Ian; POWELL, Barry (eds.) A New Companion to Homer. Leiden: Brill, 1997, p. 238260. 
SCHADEWALDT, Wolfgang. Book 11 and the lliad as "Anticipation". Translated from the German by H.M. Harvey. In: DE JONG, J. F. (ed.) Homer: Critical Assessments: vol. I - The Creation of the Poems. London: Routledge, 1999, p. 67-95.

VAN WEES, Hans. Aristocracy. In: FINKELBERG, Margalit (ed.). The Homer Encyclopedia. Volume I. Chichester; Malden: WileyBlackwell, 2011, p. 90-2.

VISSER, E. Formulae or Single Words? Towards a New Theory on Homeric Verse-Making. In: DE JONG, J. F. (ed.) Homer: Critical Assessments: vol. I - The Creation of the Poems. London: Routledge, 1999, p. 364-381.

WATKINS, Calvert. How to Kill a Dragon: Aspects of IndoEuropean Poetics. Oxford: Oxford University Press, 2001.

WEST, Martin L. The Rise of Greek Epic. Journal of Hellenic Studies, v. 108, 1988, p. 151-172

WEST, Martin L. The East Face of Helicon: West Asiatic Elements in Greek Poetry and Myth. Oxford: Clarendon Press, 1997

WEST, Martin L. The Invention of Homer. Classical Quaterly, v. 49, n. 2, 1999, p. 364-382.

WEST, Martin L. Indo-European Poetry and Myth. Oxford: Oxford University Press, 2007.

WOLF, F. A. Prolegomena to Homer (capítulos XVIII a XXII). In DE JONG, J. F. (ed.) Homer: Critical Assessments: vol. I - The Creation of the Poems. London: Routledge, 1999, p. 23-34.
WOOD, R. An Essay on the Original Genius of Homer. In: DE JONG, J. F. (ed.) Homer: Critical Assessments: vol. I - The Creation of the Poems. London: Routledge, 1999, p. 17-22.

ZUMTHOR, Paul. Introdução à Poesia Oral. Tradução de Jerusa Pires Ferreira, Maria Lúcia Diniz Pochat e Maria Inês de Almeida. São Paulo: Editora Hucitec, 1997.

Recebido em 20-10-2017. Aceito em 27-01-2018. 


\section{NOTAS}

Agradeço aos dois avaliadores anônimos, que contribuíram com sugestões incorporadas ao texto final.

2 KIRK. The Circumstances of Monumental Composition, p. 262-6.

3 Imaginando, entretanto, que um mesmo autor pode, conforme a história ou conforme o poema que compõe, ser versátil, variando seu estilo e assumindo um éthos diferente. A abordagem de Pucci .

4 JANKO. The Homeric Poems as Oral Dictated Texts, p. 135.

5 RUIJGH. D'Homère aux origines proto-mycéniennes de la tradition épique. Analyse dialectologique du langage homérique, avec un excursus sur la création de l'alphabet grec, p. 21.

WEST. The Invention of Homer 151

7 NAGY, Poetry as Performance.

8 WEST. The Invention of Homer, p. 364

9 NAGY. Homeric Questions, p. 42.

10 O funcionamento da sociedade homérica e sua dinâmica de classes não são apresentados de forma explícita nos poemas (cf. VAN WEES. Aristocracy, p. 90-2), de modo que se entende por "aristocracia", nesse caso, uma elite que concentra a maior parte das riquezas e efetividade na guerra.

11 Cf. LAMBERTON. Homer in Antiquity, p. 42. Para o tipo de leitur que se fazia dos textos homéricos, cf. RICHARDSON. Homeric Professors in the Age of Sophists. No Período Helenístico, Homero será visto como fundador e fonte para o desenvolvimento da poesia e precursor do discurso historico, etico, político, retórico, técnico e científico (cf. LAMBERTON. Homer in Antiquity, p. 46, citando uma biografia helenística, Vida e poemas de Homero, falsamente atribuída a Plutarco). Dourado-Lopes (2010) indica que contemporâneos de Xenofanes á interpretavam certas passagens dos poemas segundo um "sentido subjacente" ou "oculto" (ưróvora), e que Anaxágoras, segundo Diógenes Laercio (II, 11, 4-10) foi o primeiro a sustentar que os poemas homericos dizem respeito à virtude e a justiça", tudo isso talvez como resultado de um distanciamento em relação à visão de mundo, às ideias e às práticas do Período Arcaico (cf. DOURADO-LOPES. Natureza dos deuses e divindade da natureza: reflexôes sobre a recepção antiga e moderna do antropomorfismo divino grego, p. 381-3). Essa recepção de Homero como guia mora e enciclopédia do saber parece já vista com desconfiança por críticos da moralidade tradicional como Heráclito (no fragmento DK B 42 ou Mch 30, na traduçăo de Martim Reyes Silva: " < quanto a> Homero < dizia > digno de ser expulso dos concursos e bastonado, e

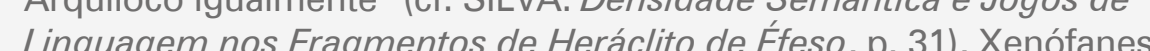
(no fragme DK B 11, na traducão de Fernando Santo , “Homero (no fro Hesío a tribuíram as du é infâmia e vergonha / roubar, raptar e enganar mutuamente", of. SANTORO Filósofos Épicos I Parmênides a Xenófanes, p. 29) Platão (principalmente no Íon e na República).

12 Homero é tambem relacionado a Quios no Hino Homerico a Apolo (3, 172-3, em traduçáa de Maria Lucia G. Massi, cf. RIBEIRO, Hinos Homericos): "E um homem cego, que mora em Quios rochosa/ todos os cantos que ele deixa para trás são os melhores". Tucídides (III, 104, 4) trata esse hino como um poema de Homero, como a llíada e a Odisseia.

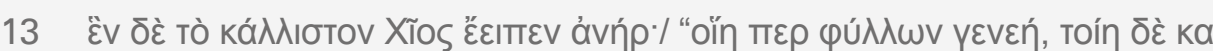
ávס̄ỗv"

14 Lembrando uma possível etimologia de rapsodo, "o que costura versos".

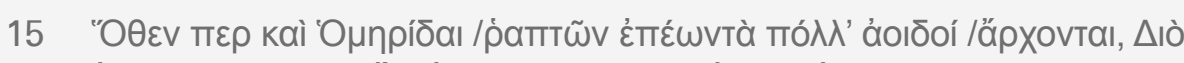

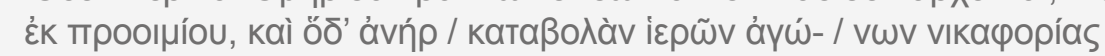

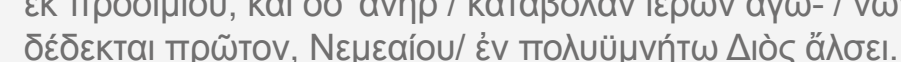

16 LAMBERTON, Homer in Antiquity, p. 33-34. 
17 'Inicialmente, chamavam de 'Homeridas' os descendentes de Mas depois, tambem os rapsodos que não mais recuam sua descendência ate Homero. Tornaram-se proeminentes os seguidores de Cineto, que diziam ter composto muitos dos versos e os inseriu na poesia de Homero. Cineto era de Quios. Dele também dizem que compôs, dentre os poemas atribuidos a Homero, o hino escrito a Apolo. Entáo esse Cineto foi o primeiro em Siracusa a recitar os versos de Homero por volta da sexagésima nona Olimpíada (ou seja, entre os anos 504 e 501), como disse Hipostrato". Schol. Pindari

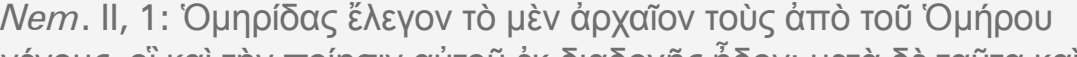

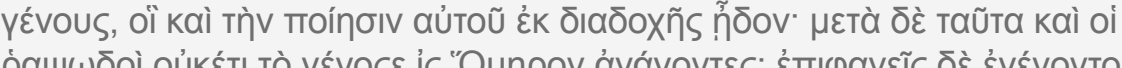

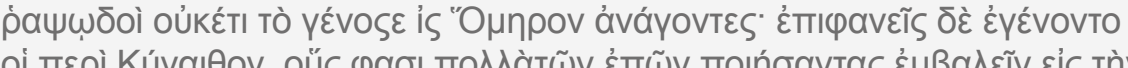

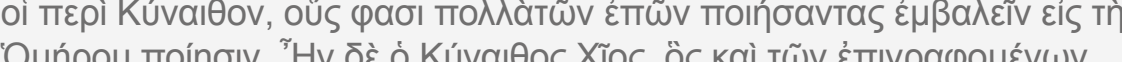
Orńn

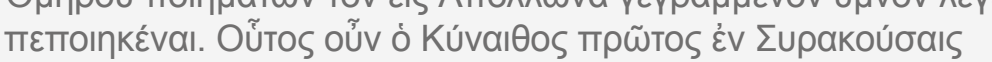

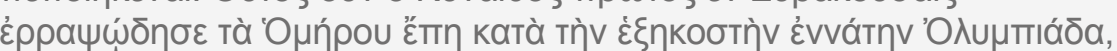
Ws IT

8 KIRK. The Circumstances of Monumental Composition, p. 257.

19 Cf. nota 13.

20 WEST. The Invention of Homer, p. 372

21 WEST. The Invention of Homer, p. 374-375.

22 NAGY. The Best of the Achaeans, p. 296-300

23 WEST. The Invention of Homer, p. 374-5.

24 FOLEY. "Reading" Homer though Oral Tradition, p. 7.

25 FOLEY. "Reading" Homer though Oral Tradition, p. 5-7.

26 Analisando os componentes estruturais mais básicos da poesia homerica, percebe-se que o metro utilizado, o hexâmetro datilico, é uma tradição que tem raizes micênicas (cf. HOEKSTRA, Epic Verse Before Homer) ou mesmo indo-europeias (WEST. The Rise of Greek Epic, p. 151). Numa perspectiva diacrônica, o metro o resultado da "fraseologia tradicional", ou seja, e formado pelo uso repetido na poesia de certos padrōes rítmicos da fala; numa perspectiva sincrônica, o metro contém ou enquadra essa "fraseologia tradicional" (NAGY. Homer's Text and Language, p. 14456). Alguns núcleos semânticos utilizados por Homero são também encontrados em sânscrito ou nas línguas germânicas (WEST. The Rise of Greek Epic, p. 154-5) e algumas caracteristicas narrativas e poéticas possivelmente sofrem a influência de obras do Oriente Proximo (Para uma aproximação com a tradição indo-europeia, cf. WATKINS. How to Kill a Dragon, e WEST. Indo-European Poetry and Myth. Para uma aproximaçao com textos orientais, cf. BURKERT. The Orientalizing Revolution, 1995, WEST. The East Face of Helicon, e LOUDEN. Homer's Odyssey and the Near East). O grego de Homero paz em a

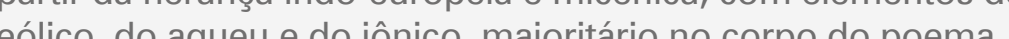
RULGH D'Homère aux origines proto-mycéniennes de la tradition exique Analyse dialectologique du langage homérique avec un excursus sur la création de l'alphabet grec, p. 1-3. West The Rise of Greek Epic, p. 69). Ruiigh sugere uma "ambiência eubia" para "versão definitiva" (cf. RUIJGH. D'Homère aux origines protomycéniennes de la tradition épique. Analyse dialectologique du langage homérique, avec un excursus sur la création de l'alphabet grec p. 3). Para West, "a partir da metade do século VIII, a épica grega arcaica se torna pan-helênica e seu dialeto e convenções se tornam fixos e disponíveis para a imitação de poetas de toda parte" (WEST. The Rise of Greek Epic, p. 172). Por um raciocínio semelhante, Kirk imagina a composição na Jônia, mas aceita que os dois poemas podem ter sido compostos em qualquer lugar quando o jônico já era estabelecido tradicionalmente como base dialetal apropriada para a epica (cf. KIRK. The Circumstances of Monumental Composition, p. 257). Na prática, mais do que qualquer garantia sobre a origem e desenvolvimento da poesia epica arcaica, o metro as variaçoes dialetais parecem contribuir com a ampliaçăo do leque a possibilidades de um poeta para construir seus versos da maneir que lhe convém. 
27 Essa breve exposição sobre o trabalho dos filólogos de Alexandria parte de NAGY. Poetry as performa as variantes identificadas pelos alexandrinos são variaçoes de performance caracteristicas da composição e transmissão oral da tradição épica arcaica, ou seja, não um registro de alterações e correçōes, mas da "movência" do texto oral. Ainda aqui neste artigo será considerado esse caráter oral da poesia homérica. Sobre a transmissão do texto e o trabalho filológico dos alexandrinos, cf. a apresentação de Allen em HOMERI. llias, v. 1, p. 194-216 e REYNOLDS; WILSON. Scribes and Scholars, p. 5-16. O princípio

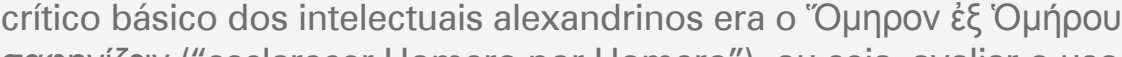
a

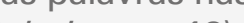
olars, p. 13).

28 Apoiando-se, por exemplo, no depoimento de Josefo (Contra Apion, I, 2) da preservação dos poemas a princípio pelo canto e pela memória e seu posterior registro escrito. Cf. WOLF. Prolegomena to Homer, p. 23-4, uma seleção de trechos dos Prolegomena direcionada para esse detalhe feita por De Jong para sua coletânea de estudos homéricos.

29 Cf. MAHLER, Did Philologists write the lliad?: Friedrich August Wolf's criteria of style and the demonstrative power of citation, p. 187-191.

30 Cf. WOOD. An Essay on the Original Genius of Homer, p. 17-21, texto de 1769, que propõe que a composição dos poemas é anterior introduça do alfabeto no mundo grego.

31 DODDS. Introduction: Homer, p. 3-12.

32 DODDS. Introduction: Homer, p. 4.

33 DODDS. Introduction: Homer, p. 6.

34 SCHADEWALDT. Book 11 and the lliad as "Anticipation", p. 87.

35 Para uma história das primeiras edições impressas de Homero do século XVI ao início do XX, cf. a exposição de Allen em HOMERI. llias, v. 1, p.248-72
36 SCHADEWALDT. Book 11 and the lliad as "Anticipation", p. 88.

37 DODDS. Introduction: Homer, p. 8.

38 NAGY. Poetry as Performance.

39 DODDS. Introduction: Homer, p. 9-11.

40 Segundo Foley, a maior parte das regiões visitadas por Parry e Lord para coletar canções e conversar com compositores (guslari) Oral Tradition, p. 3). Foley ainda indi. a infuência do though Matija Murko para a realização dessa pesquisa de campo. Quanto à Segunda Guerra Mundial, Bakker a considera uma das causas para a demora com que as ideias de Parry se espalharam entre os acadêmicos com interesse em Estudos Clássicos (BAKKER. Introduction: Homer and Oral Poetry Research, p. 164). Nos anos 60 do século $X X$, pesquisas sobre o estilo oral e a fórmula se tornariam um dos setores mais promissores dos estudos homéricos.

41 PARRY. Studies in the Epic Technique of Oral Verse-Making. 1 Homer and Homeric Style, p. 272-315.

42 PARRY. Studies in the Epic Technique of Oral Verse-Making. 1 Homer and Homeric Style, p. 272

43 PARRY. The Epithet and the Formula I: The Usage of the Fixed Epithet, p. 39.

44 PARRY. The Epithet and the Formula l: The Usage of the Fixed Epithet, p. 42.

45 PARRY. The Epithet and the Formula l: The Usage of the Fixed Epithet, p. 42-3.

46 PARRY. Studies in the Epic Technique of Oral Verse-Making. 1 Homer and Homeric Style, p. 324

47 Foley assim avalia a influência da teoria oral para além dos Estudos Clássicos: "nos anos seguintes, a 'teoria oral' foi expandida enormemente da comparação inicial entre Homero e a épica sul-
eslava para incluir mais de 150 tradições orais diferentes de seis 
dos sete continentes e dos tempos antigos até os dias modernos" FOLEY. "Reading" Homer though Oral Tradition, p. 4).

48 AREND. Die typische Scenen bei Homer.

49 PARRY. On Typical Scenes in Homer, p. 405.

50 LORD. Composition by Theme in Homer and Southslavic Epos, p. 73

51 LORD. Composition by Theme in Homer and Southslavic Epos, p. 72.

52 As traduções são de Christian Werner (cf. HOMERO. Odisseia). texto grego das tres passagens e o seguinte: Odisseia, t, 146-

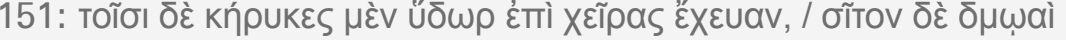

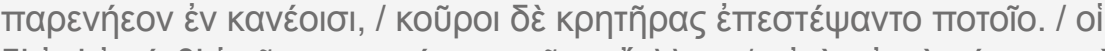

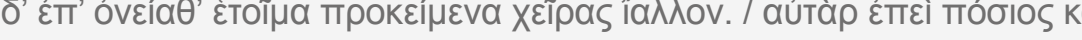

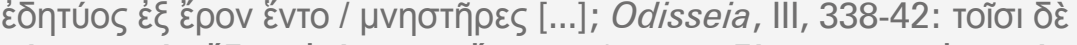

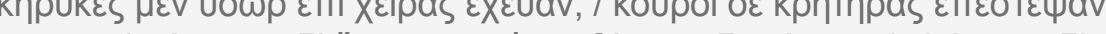

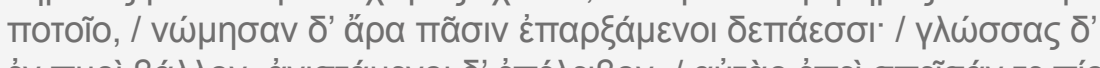

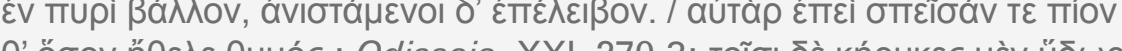

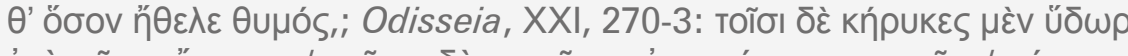

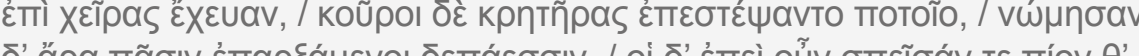

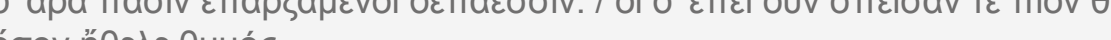

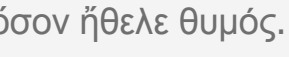

53 LORD. Composition by Theme in Homer and Southslavic Epos, p. 74

54 Foley, lendo entrevistas de Parry e Lord com os guslari eslavos, mostra como para eles uma "palavra" (reč) não tem relação com o item que definimos tipograficamente como palavra, mas com uma unidade maior, composta do que seriam muitas palavras escritas. Em outros contextos, pode significar uma fala, uma cena, uma narrativa (FOLEY, "Reading" Homer though Oral Tradition, p. 9).

55 LORD. The Singer of Tales, p. 16-7.

56 LORD. The Singer of Tales, p. 25-6.

57 LORD. The Singer of Tales, p. 99

58 LORD. The Singer of Tales, p. 99-102.
59 RUSSO. The Formula, p. 244.

60 RUSSO. The Formula, p. 245-7.

61 EDWARDS. Homeric Style and Oral Poetics, p. 265.

62 RUSSO. The Formula, p. 247.

63 RUSSO. The Formula, p. 248.

64 EDWARDS. Homeric Style and Oral Poetics, p. 264-5.

65 RUSSO. The Formula, p. 246-7.

66 EDWARDS. Homeric Style and Oral Poetics, p. 274.

67 LORD. The Singer of Tales, p. 35-6, enfatizado em RUSSO. The Formula, p.243.

68 EDWARDS. Homeric Style and Oral Poetics, p. 262-3.

69 BAKKER. Introduction: Homer and Oral Poetry Research, p. 169-70.

70 EDWARDS, Homeric Style and Oral Poetics, p. 272-3.

71 EDWARDS. Homeric Style and Oral Poetics, p. 274.

72 AUSTIN. Archery at the Dark of the Moon, p. 31-9.

73 AUSTIN. Archery at the Dark of the Moon, p. 50.

74 AUSTIN. Archery at the Dark of the Moon p. 51.

75 VISSER. Formulae or Single Words? Towards a New Theory on Homeric Verse-Making, p. 369-76.

76 RUSSO. The Formula, p. 257.

77 ZUMTHOR. Introdução à Poesia Oral, p. 121

78 BAKKER. The Study of Homeric Discourse, p. 172-3.

79 BAKKER. The Study of Homeric Discourse, p. 300

80 BAKKER. The Study of Homeric Discourse, p. 304. 
81 EDWARDS. Homeric Style and Oral Poetics, p. 267.

82 "Lá eu, atrás de prêmios pelo aguerrido Anfidamas, / até Cálquis cruzei - em profusão esses anunciados / prêmios fixaram o filho do enérgico- - onde, afimo ou/con un canto ter vencido e trazido Trabalhos e Dias.

3 KIRK. The Circumstances of Monumental Composition, p. 259-61.

84 BAKKER. The Study of Homeric Discourse, p. 174

85 Para uma exposição sobre a transmissão dos manuscritos dos poemas homéricos desde a Antiguidade, cf. HASLAM. Homeric Papyri and the Transmission of the Text.

86 JANKO. The Homeric Poems as Oral Dictated Texts, p. 12-3.

87 NAGY. Homeric Questions, p. 50-2.

88 NAGY. Poetry as Performance, p. 109-10.

89 Os textos entre colchetes são acréscimos que retomam as explicações dos conceitos apresentados pelo próprio autor ao ongo do livro. Papiros anteriores ao período de Aristarco e que não apresentam no texto marcas da divisão em 24 cantos. Cf. Bird, 2010.

a koIvń, seria a edição ateniense de Demétrio de Fálero a partir de uma suposta recensão de Aristóteles. Os escólios não fariam menção direta a essas edições porque elas teriam sido incorporadas à de Zenódoto, predecessor de Aristarco. A divisão alexandrina em 24 cantos (correspondente ao número de letras do alfabeto grego) seria baseada na prática das performances.

91 http://www.homermultitext.org/ com acesso em 29 de setembro de

92 BOWRA. Tradition and Design, p. 47

93 KULLMANN. Oral Poetry and Neoanalysis in Homeric Research, $\mathrm{p}$. 45-50.
94 Nessa concepção o poema teria sido escrito pelo próprio poeta, não ditado conforme o modelo de Lord e de que o projeto de passar a tradiçao oral para a escrita poderia ter vindo do oriente, como o próprio alfabeto grego, adaptado do fenicio (cf. KULLMANN. Oral Poetry and Neoanalysis in Homeric Research, p. 154-7).

95 Cf. ROUSSEAU. L'intrigue de Zeus.

96 Cf. MARKS. Zeus in the Odyssey.

97 Cf. FOLEY. Oral Tradition and its Implication e FOLEY. Homer's Traditional Art.

98 Cf. GRAZIOSI; HAUBOLD. Homer: the Resonance of Epic.

99 FOLEY. Oral Tradition and its Implication, p. 165.

100 FOLEY. Oral Tradition and its Implication, p. 167-8.

101 FOLEY. Homer's Traditional Art, p. 15.

102 FOLEY. Homer's Traditional Art, p. 27.

103 KELLY. A Referential Commentary and Lexicon to Homer, p. 4-9.

104 KELLY. Tradição na Épica Grega Antiga, p. 16-7.

105 GRAZIOSI; HAUBOLD. Homer: the Resonance of Epic, p. 12-3.

106 GRAZIOSI; HAUBOLD. Homer: the Resonance of Epic, p. 26.

107 GRAZIOSI; HAUBOLD. Homer: the Resonance of Epic, p. 53-5.

108 MALTA. Homero Múltiplo. p. 14-5.

109 BRANDÃO. Antiga Musa, p. 23 